\title{
PENGARUH MODEL DAN CARA PENILAIAN TERHADAP HASIL BELAJAR IPA DENGAN MENGONTROL PENGETAHUAN AWAL MATEMATIKA SISWA
}

\author{
Adam Rumbalifar \\ Dosen Prodi Pendidikan Fisika \\ Jurusan MIPA FKIP Universitas \\ Pattimura Ambon Maluku
}

\author{
Alamat Korespondensi \\ Dosen Prodi Pendidikan Fisika \\ Jurusan MIPA FKIP Universitas \\ Pattimura Ambon Maluku \\ e-mail: \\ alfian lifars@yahoo.co.id
}

\begin{abstract}
This research aims to study the effect of models and how to assess toward science achievement by controlling previous knowledge mathematics of students. This study conducted at SMP Negeri I, SMP Negeri 2, and SMP Negeri 3 Bula East Seram district with a population of 295 students. This study used a quasi-experimental method $2 \times 3$ factorial design using the cell mean univariate models with model covariates Analysis (ANCOVA) which variables are: (I) the dependent variable or response variable and (2) the independent variable. The results by controlling previous mathematics of students obtained: (I) the science achievement of students who were given a written test assessment models is higher than the group given peer assessment model, (2) science group of students who were given a written test assessment models is higher than the $a$ given model of self-assessment, (3) science achievement of students who were given the peer assessment model is higher than the group given the self-assessment models, (4) science achievement of students who are given the analytical assessment method is higher than the group given the way holistic assessment, (5) there is interaction between asses models by way of assessment of science achievement, (6) special group of students who were given an analytical assessment methods, achievement assessment model of science written test is higher than the inter theme asses models, (7) special groups of students were given an analytical assessment methods, achievement assessment model of science written test is higher than the self-assessment models, (8) a special group of students who were given an analytic way of assessment of achievement assessment model of science higher peer self-assessment model, (9) specific groups of students were given ways holistic assessment of achievement assessment model of science written test is higher than the peer assessment model, (10) a special group of students who were way holistic assessment of achievement assessment model of science written test is higher than the self-assessment models, (I I) special groups of students were given ways holistic assessment of achievement assessment model of science higher peer self-assessment model, (12) a special group of students who use the model written assessment of achievement assessment models of science analytic way higher than holistic assessment method, (13) specific groups of students using peer asses model of achievement assessment models of science analytic way higher than holistic assessment method, and (14) special groups of students who use the self-assessment model of science achievement assessment means higher analytic holistic assessment of the way.
\end{abstract}

\section{Keywords}

model assessment, how to asses, achievement of science, previous knowledge of mathematics.

\footnotetext{
ABSTRAK

Penelitian ini bertujuan untuk mempelajari pengaruh model penilaian dan cara penilaian terhadap hasil belajar IPA dengan mengontrol pengetahuan awal matematika siswa, penelitian ini dilaksanakan di SMP Negeri I, SMP Negeri 2, dan SMP Negeri 3 Bula Kabupaten Seram Bagian Timur dengan jumlah populasi 295 siswa. Penelitian ini menggunakan metode kuasi eksperimen dengan desain faktorial $2 \times 3$ yang menggunakan model rerata sel univariat dengan model Analisis Kovariat (ANKOVA) yang variabelnya terdiri dari: (I) variabel terikat atau variabel respon dan (2) variabel bebas. Dari hasil yang diperoleh dengan mengontrol pengetahuan awal matematika siswa sebagai berikut: (I) hasil belajar IPA kelompok siswa yang diberi model penilaian tes tertulis lebih tinggi dari kelompok yang diberi model penilaian antar teman, (2) hasil belajar IPA kelompok siswa yang diberi model penilaian tes tertulis lebih tinggi dari kelompok yang diberi model penilaian diri, (3) hasil belajar IPA kelompok siswa yang diberi model penilaian antar teman lebih
} 
tinggi dari kelompok yang diberi model penilaian diri, (4) hasil belajar IPA kelompok siswa yang diberi cara penilaian analitik lebih tinggi dari kelompok yang diberi cara penilaian holistik, (5) terdapat interaksi antara model penilaian dengan cara penilaian terhadap hasil belajar IPA, (6) khusus kelompok siswa yang diberi cara penilaian analitik, hasil belajar IPA model penilaian tes tertulis lebih tinggi dari model penilaian antar teman, (7) khusus kelompok siswa yang diberi cara penilaian analitik, hasil belajar IPA model penilaian tes tertulis lebih tinggi dari model penilaian diri, (8) khusus kelompok siswa yang diberi cara penilaian analitik hasil belajar IPA model penilaian antar teman lebih tinggi dari model penilaian diri, (9) khusus kelompok siswa yang diberi cara penilaian holistik hasil belajar IPA model penilaian tes tertulis lebih tinggi dari model penilaian antar teman, (I0) khusus kelompok siswa yang diberi cara penilaian holistik hasil belajar IPA model penilaian tes tertulis lebih tinggi dari model penilaian diri, (I I) khusus kelompok siswa yang diberi cara penilaian holistik hasil belajar IPA model penilaian antar teman lebih tinggi dari model penilaian diri, (12) khusus kelompok siswa yang menggunakan model penilaian tertulis hasil belajar IPA cara penilaian analitik lebih tinggi dari cara penilaian holistik, (I3) khusus kelompok siswa yang menggunakan model penilaian antar teman hasil belajar IPA cara penilaian analitik lebih tinggi dari cara penilaian holistik, dan (14) khusus kelompok siswa yang menggunakan model penilaian diri hasil belajar IPA cara penilaian analitik lebih tinggi dari cara penilaian holistik.

Kata Kunci

model penilaian, cara penilaian, hasil belajar IPA, pengetahuan awal matematika

\section{Pendahuluan}

Pendidikan merupakan salah satu wahana pembinaan keluarga, pemerintah dan masyarakat yang harus dilakukan secara terpadu untuk meningkatkan serta mengubah perilaku guna meningkatkan kualitas sumber daya manusia Indonesia menjadi lebih baik. Kualitas pendidikan sangat ditentukan oleh kemampuan satuan pendidikan dalam mengelola proses pembelajaran. Penilaian merupakan bagian yang penting dalam pembelajaran. Dengan melakukan penilaian, pendidik sebagai pengelola kegiatan pembelajaran dapat mengetahui kemampuan yang dimiliki peserta didik, ketepatan metode mengajar yang digunakan, dan keberhasilan peserta didik dalam meraih kompetensi yang telah ditetapkan. Berdasarkan hasil penilaian, pendidik dapat mengambil keputusan secara tepat untuk menentukan langkah yang harus dilakukan selanjutnya.

Hasil belajar adalah perubahan yang terjadi sebagai akibat dari kegiatan belajar yang telah dilakukan oleh individu. Untuk mencapai perubahan itu harus melalui proses tertentu yang dipengaruhi oleh faktor dari dalam diri individu dan di luar individu. Karena proses belajar bersifat psikologis, maka dikatakan bahwa seseorang telah mengalami proses belajar apabila dilihat dari hasil belajarnya, misalnya dari tidak tahu menjadi tahu, tidak mengerti menjadi mengerti, dari tidak berilmu menjadi berilmu, dan sebagainya. Sementara itu belajar fisika dapat diartikan sebagai suatu aktivitas mental untuk memahami arti dan hubungan-hubungan serta simbol, kemudian diterapkan pada situasi nyata. Belajar fisika berkaitan dengan apa dan bagaimana menggunakannya dalam membuat keputusan untuk memecahkan masalah. Belajar fisika melibatkan pengamatan, penyelidikan, dan keterkaitannya dengan fenomena fisik dan sosial. Berkaitan dengan itu, maka belajar fisika merupakan suatu kegiatan yang berkenaan dengan penyelesaian rumus-rumus yang sederhana dan merupakan himpunan rumus-rumus baru yang selanjutnya membentuk himpunan rumus-rumus baru yang lebih rumit.

Nitko (1996: 4) mengatakan bahwa, penilaian adalah suatu proses pengumpulan informasi untuk digunakan dalam pengambilan keputusan tentang siswa, kurikulum, program, dan kebijakan yang berhubungan dengan pendidikan. Sementara itu menurut Popham (1995: 2-3) penilaian sebagai suatu cara untuk mendeskripsikan pengukuran dalam pendidikan yang dilakukan oleh guru, di mana dekriptornya 
mencakup tes tertulis secara tradisional yang berisi berbagai prosedur pengukuran. Sedangkan definisi operasional penilaian yang biasa digunakan dalam konteks pendidikan adalah suatu usaha formal untuk menentukan status siswa berkenaan dengan variabel-variabel bidang pendidikan yang menjadi perhatian. Dengan demikian secara umum penilaian dalam pendidikan dapat didefinisikan sebagai suatu proses pengumpulan data sebagai informasi guna membuat keputusan tentang apa yang telah dicapai oleh seorang siswa dalam pembelajaran.

Ibrahim dan Nur (2000: 47) mengemukakan bahwa penilaian adalah proses pengumpulan informasi selengkap-lengkapnya tentang siswa dan kelas untuk tujuan pembuatan keputusan pengajaran. Selanjutnya menjelaskan bahwa penilaian adalah pembuatan keputusan, pemberian nilai, atau keputusan tentang manfaat suatu program, pendekatan, atau kerja siswa tertentu. Sementara itu Djaali dan Mulyono (2000: 10) menjelaskan bahwa tes secara umum dapat diartikan sebagai alat yang dipergunakan untuk mengukur pengetahuan atau penguasaan objek ukur terhadap seperangkat konten atau materi tertentu. Lebih lanjut Bruce yang dikutip Djaali dan Mulyono (2000: II) mengatakan bahwa tes dapat mengukur banyaknya pengetahuan yang diperoleh individu dari bahan pelajaran yang terbatas pada tingkat tertentu. Dalam kaitannya dengan proses penilaian di kelas, seorang penilai dapat melakukan berbagai macam bentuk penilaian, seperti penilaian diri, penilaian antar teman, dan tes tertulis, atau bentuk penilaian lainnya. Sementara itu penilaian diri di tingkat kelas (classroom self assessment) adalah penilaian yang dilakukan sendiri oleh guru atau siswa yang bersangkutan untuk kepentingan pengelolaan kegiatan pembelajaran di kelas. Tola (2008: vi-4) kesempatan peserta didik dan guru untuk dapat merefleksi dan menilai diri adalah merupakan dasar untuk mendorong dirinya agar: (I) bertanggung jawab terhadap belajar dan mengajar, (2) mempromosi pemikiran kritis, dan (3) membantu peserta didik menjadi terlibat secara aktif didalam proses pendidikannya. Oleh karena itu penilaian diri memiliki fungsi sebagai pendorong untuk setiap peserta didik guna meningkatkan model pembelajaran sesuai kemampuan perkembangannya dan merancang tujuan KBM nya secara realistis. Dengan demikian secara umum tes dapat diartikan sebagai alat atau instrumen yang digunakan oleh seorang guru dalam mengukur tingkat ketercapaian siswa pada indikator tertentu.

Bostock (diakses tanggal 5 Oktober 20l0: I) menyatakan bahwa penilaian antar teman (peer assesment) merupakan proses penilaian siswa oleh siswa lainnya baik formatif untuk mendapatkan umpan balik ataupun untuk ujian sumatif kenaikan kelas yang bertujuan untuk memperbaiki kualitas belajar dan memberikan kesempatan kepada siswa untuk dapat melakukan penilaian. Dalam segi penilaian sumatif hasil studi menunjukkan bahwa sistem penilaian oleh sesama siswa menjadi valid dan reliabel. Dalam kaitannya dengan proses penilaian, seorang penilai dapat melakukannya dengan cara holistik dan analitik. Menurut Metler (diakses tanggal I8 Oktober 2010: I-2) cara penilaian analitik adalah cara penilaian yang mengharuskan para penilai dapat menentukan daftar unsur-unsur penting yang harus dinilai. Lebih lanjut Metler mengatakan bahwa cara penilaian analitik adalah setiap hasil kinerja (performance) individu dinilai, selanjutnya nilai individu dijumlahkan untuk memperoleh nilai total. Sedangkan cara penilaian holistik, yaitu: mengharuskan guru untuk melakukan proses penilaian hasil belajar secara keseluruhan, tanpa memperhatikan komponen-komponen lainnya.

Dalam kaitannya dengan tes, Crocker dan Algina yang dikutip Silverius (I99I: 4-5) mengemukakan bahwa tes adalah suatu proses baku untuk memperoleh sampel tingkah laku dari suatu ranah tertentu. Lebih lanjut dikatakan bahwa tes adalah suatu prosedur sistematis untuk mengamati dan menandakan satu atau lebih karakteristik seseorang dengan menggunakan skala numerik atau sistem kategori. Sehingga dengan demikian tes tertulis merupakan sekumpulan perangkat pertanyaan yang disusun secara sistematis berdasarkan kaidah yang telah ditetapkan.

Dari teori yang ada maka penilaian antar teman dapat diartikan sebagai suatu kegiatan penilaian yang melibatkan siswa secara utuh dengan meminta siswa dapat menilai siswa lainnya. Sementara ini penilaian analitik 
merupakan suatu proses penilaian yang dilakukan oleh penilai berdasarkan langkah-langkah yang telah ditentukan oleh seorang penilai, sedangkan penilaian holistik merupakan suatu proses penilaian yang dilakukan tanpa meperhatikan bagian-bagian yang harus dinilai, atau dengan kata lain penilaian holistik merupakan proses penilaian yang dilakukan oleh seorang penilai secara menyeluruh.

\section{Metode Penelitian}

Metode yang digunakan dalam penelitian ini adalah metode kuasi eksperimen dengan variabel penelitian terdiri atas: (I) variabel terikat atau variabel respon dan (2) variabel bebas. Adapun variabel terikatnya (criterion) atau variabel respon adalah Hasil belajar IPA siswa (Y), sedangkan variabel bebasnya adalah: (I) faktor model penilaian (assessment model), yang terdiri dari faktor model penilaian tes tertulis, faktor model penilaian diri, dan faktor model penilaian antar teman, dan (2) faktor cara penilaian, dengan faktor cara penilaian holistik dan faktor cara penilaian analitik. Keduanya dijadikan sebagai faktor perlakuan (treatment).

Untuk memperoleh kedua data tersebut di atas dikembangkan instrumen berupa: (I) penilaian hasil belajar IPA diperoleh melalui tes, yang dilakukan dengan bentuk pilihan ganda dan essay yang mengacu pada dimensi kognitif dari Bloom dan (2) pengukuran terhadap kemampuan awal matematika siswa dengan mengacu kepada nilai kemampuan yang sudah ada pada hasil ujian nasional (UN) mata pelajaran matematika.

Berdasarkan teori dan permasalahan maka desain yang digunakan dalam penelitian ini adalah desain faktorial $2 \times 3$ dengan menggunakan model Analysis of Covariance (ANCOVA) yang desainnya seperti pada Tabel I berikut ini:

Tabel I. Desain Eksperimen Faktorial $2 \times 3$

\begin{tabular}{|c|c|c|c|}
\hline \multirow[b]{2}{*}{$\begin{array}{c}\text { Cara } \\
\text { Penilaian } \\
\text { (B) }\end{array}$} & \multicolumn{3}{|c|}{ Model Penilaian(A) } \\
\hline & $\begin{array}{c}\text { Tes } \\
\text { Tertulis } \\
\text { (AI) }\end{array}$ & $\begin{array}{c}\text { Penilaian } \\
\text { Antar Teman } \\
\text { (A2) }\end{array}$ & $\begin{array}{l}\text { Penilaian } \\
\text { Diri (A3) }\end{array}$ \\
\hline $\begin{array}{l}\text { Holistik } \\
\text { (BI) }\end{array}$ & $\begin{array}{c}{[X, Y]_{1 / k}} \\
k=I, 2, \ldots, n_{\| I}\end{array}$ & $\begin{array}{c}{[\mathrm{X}, \mathrm{Y}]_{21 \mathrm{k}}} \\
\mathrm{k}=\mathrm{I}, 2, \ldots, \mathrm{n}_{21}\end{array}$ & $\begin{array}{c} \\
{[X, Y]_{31 k}} \\
k=1,2, \ldots, n_{31}\end{array}$ \\
\hline $\begin{array}{l}\text { Analitik } \\
\text { (B2) }\end{array}$ & $\begin{aligned} & {\left[X_{1}, Y\right]_{12 k} } \\
k= & I, 2, \ldots, n_{12}\end{aligned}$ & $\begin{array}{r}{\left[X_{1}, Y\right]_{22 k}} \\
k=1,2, \ldots, n_{22}\end{array}$ & $\begin{array}{c}{\left[\mathrm{X}_{1}, \mathrm{Y}\right]_{32 \mathrm{k}}} \\
\mathrm{k}=\mathrm{I}, 2, \ldots, \mathrm{n}_{32}\end{array}$ \\
\hline
\end{tabular}

Sementara itu perlakuan yang diberikan dalam penelitian ini adalah cara penilaian holistik dan cara penilaian analitik dengan menggunakan model penilaian tes tertulis (paper and pencils assessment), model penilaian antar teman (peer assessment), dan model penilaian diri (self assessment) yang terdiri dari item-item tes essay dan multiple choice (pilihan ganda). Sebelum dilakukan analisis terhadap hasil penelitian maka terlebih dahulu dilakukan uji persyaratan analisis yakni: (I) uji normalitas, (2) uji homogenitas, (3) uji linieritas, (4) uji keberartian regresi, dan (5) uji kesejajaran garis.

\section{Hasil Penelitian}

Setelah memenuhi semua uji persyaratan analisis maka dilanjutkan proses pengolahan data. Data diolah melalui program aplikasi SPSS dengan model analisis yang digunakan adalah analisis kovarian (ANKOVA). Pertama-tama menggunakan prosedur GLM Univariate dengan tujuan untuk dapat menguji pengaruh faktor utama (main effect) dan pengaruh faktor interaksi terhadap hasil belajar IPA setelah mengontrol pengetahuan awal matematika siswa. Diperoleh hasil uji hipotesis khusus model penilaian dengan hasil analisis pengujian hipotesis menunjukkan bahwa nilai statistik untuk Uji-F terlihat bahwa nilai $F_{\text {hit }}=12,207>F_{\text {tab }}=2,70$ artinya terdapat perbedaan hasil belajar IPA siswa antara kelompok yang diberikan model penilaian tes tertulis, model penilaian antar teman, dan model penilaian diri setelah mengontrol pengetahuan awal matematika siswa. Selanjutnya dari nilai statistik Uji-t di mana nilai $t_{0}=2, \mid 146$ dan nilai $t_{\text {tabel }}=1,684$ pada taraf signifikansi $\alpha=0,05$. Dengan demikian nilai $t_{0}=2,146>t_{\text {tabel }}=1,684$ artinya bahwa hasil belajar IPA siswa dalam kelompok yang diberikan model penilaian mempunyai perbedaan yang signifikan.

Selanjutnya dari hasil analisis terhadap hipotesis penelitian diperoleh hasil sebagai berikut: hipotesis (I) menunjukkan bahwa di mana nilai $t_{0}=3,062$ dan nilai $t_{\text {tabel }}=1,697$ pada taraf signifikansi $\alpha=0,05$ dengan demikian nilai $t_{0}$ $=3,062>t_{\text {tabel }}=1,697$ artinya bahwa hasil belajar IPA dalam kelompok siswa yang diberi model penilaian tes tertulis $\left(A_{I}\right)$ lebih besar dari 
kelompok siswa yang diberi model penilaian antar teman $\left(A_{2}\right)$ setelah mengontrol pengetahuan awal matematika siswa; hipotesis (2) di mana nilai $t_{0}=$ 2,370 dan nilai $t_{\text {tabel }}=1,697$ pada taraf signifikansi $\alpha=0,05$ dengan demikian nilai $\mathrm{t}_{\mathrm{o}}=2,370>\mathrm{t}_{\text {tabel }}=$ I,697 artinya bahwa hasil belajar IPA dalam kelompok siswa yang diberi model penilaian tes tertulis $\left(A_{1}\right)$ lebih besar dari pada kelompok siswa yang diberi model penilaian diri $\left(A_{3}\right)$ setelah mengontrol pengetahuan awal matematika siswa; hipotesis (3) di mana nilai $t_{0}=2.103$ dan nilai $t_{\text {tabel }}$ $=1,697$ pada taraf signifikansi $\alpha=0,05$ sehingga dengan demikian nilai $t_{0}=2,107>t_{\text {tabel }}=1,697$ artinya bahwa hasil belajar IPA dalam kelompok siswa yang diberi model penilaian antar teman $\left(A_{2}\right)$ lebih besar dari kelompok siswa yang diberi model penilaian diri $\left(A_{3}\right)$ setelah mengontrol pengetahuan awal matematika siswa; hipotesis (4) khusus pada faktor (B) terlihat bahwa nilai $t_{\text {hit }}=$ $2,|3|<t_{\text {tabel }}=1,697$ artinya bahwa nilai rerata kelompok siswa yang dibentuk oleh cara penilaian analitik $\left(B_{1}\right)$ lebih besar dari nilai rerata kelompok siswa yang dibentuk oleh cara penilaian holistik $\left(B_{2}\right)$ setelah mengontrol pengetahuan awal matematika siswa; hipotesis (5) interakasi antar faktor (A) dan (B) diperoleh hasil nilai $F_{\text {hit }}=9,117$ $>F_{t a b}=2,70$ kemudian setelah dilanjutkan dengan uji-t diperoleh nilai $t_{0}=4,139>t_{\text {tab }}=1,697$ pada taraf signifikansi $\alpha=0,05$ artinya bahwa terdapat interaksi antara model penilaian dengan cara penilaian terhadap hasil belajar IPA setelah mengontrol pengetahuan awal matematika siswa; hipotesis (6) menunjukkan bahwa nilai statistik $F_{\text {hit }}$ $=10,329>F_{\text {tab }}=2,70$ kemudian setelah dilakukan uji-t didapat nilai $\mathrm{t}_{\text {hit }}=3,466>\mathrm{t}_{\mathrm{tab}}=1,697$ artinya bahwa terdapat perbedaan hasil belajar IPA siswa antara kelompok yang dibentuk oleh cara penilaian untuk semua model penilaian setelah mengontrol pengetahuan awal matematika siswa; hipotesis (7) menunjukkan bahwa hasil nilai statistik Uji-t di mana terdapat nilai $t_{\text {hit }}=2,622>$ $t_{\text {tab }}=1,697$ artinya bahwa khusus pada cara penilaian analitik hasil belajar IPA siswa pada kelompok yang diberi model penilaian tes tertulis $\left(A_{1}\right)$ lebih besar dari pada hasil belajar IPA kelompok siswa yang diberi model penilaian diri $\left(A_{3}\right)$ setelah mengontrol pengetahuan awal matematika siswa; hipotesis (8) menunjukkan bahwa nilai statistik Uji-t dengan $t_{\text {hit }}=2,476>$ $\mathrm{t}_{\text {tab }}=1,697$ bahwa khusus pada cara penilaian analitik hasil belajar IPA siswa pada kelompok yang diberi model penilaian antar teman $\left(A_{2}\right)$ lebih besar dari pada hasil belajar IPA kelompok siswa yang diberi model penilaian diri $\left(A_{3}\right)$ setelah mengontrol pengetahuan awal matematika siswa; hipotesis (9) menunjukkan bahwa nilai statistik Uji-t diperoleh nilai $t_{\text {hit }}=2,60 \mathrm{I}>t_{\mathrm{tab}}=1,697$ artinya bahwa khusus pada cara penilaian holistik hasil belajar IPA siswa pada kelompok yang diberi model penilaian tes tertulis $\left(A_{1}\right)$ lebih besar dari model penilaian antar teman $\left(A_{2}\right)$ setelah mengontrol pengetahuan awal matematika siswa; hipotesis (10) menunjukkan bahwa nilai statistik Uji-t diperoleh nilai $t_{\text {hit }}=3,058>t_{\text {tab }}=1,697$ artinya bahwa khusus pada cara penilaian holistik hasil belajar IPA siswa pada kelompok yang diberi model penilaian tes tertulis $\left(A_{1}\right)$ lebih besar dari pada hasil belajar IPA kelompok siswa yang diberi model penilaian diri $\left(A_{3}\right)$ setelah mengontrol pengetahuan awal matematika siswa; hipotesis (II) menunjukkan bahwa nilai statistik Uji-t diperoleh nilai $t_{\text {hit }}=4,406>t_{\text {tab }}=1,697$ artinya bahwa khusus pada cara penilaian holistik hasil belajar IPA siswa pada kelompok yang diberi model penilaian antar teman $\left(A_{2}\right)$ lebih besar dari pada hasil belajar IPA kelompok siswa yang diberi model penilaian diri $\left(A_{3}\right)$ setelah mengontrol pengetahuan awal matematika siswa; hipotesis (I2) dengan statistik Uji-t diperoleh nilai $t_{\text {hit }}=$ 2,897 $>t_{\text {tab }}=1,697$ artinya bahwa hasil belajar IPA kelompok siswa yang diberi model penilaian tes tertulis $\left(A_{1}\right)$ yang dibentuk oleh cara penilaian analitik $\left(B_{1}\right)$ lebih besar dari pada kelompok siswa yang dibentuk oleh cara penilaian holistik $\left(B_{2}\right)$ setelah mengontrol pengetahuan awal matematika siswa; hipotesis (13) menunjukkan bahwa nilai statistik Uji-t diperoleh nilai $t_{\text {hit }}=3,747>\mathrm{t}_{\text {tab }}=$ I,697 artinya bahwa hasil belajar IPA kelompok siswa yang diberi model penilaian antar teman $\left(A_{2}\right)$ yang dibentuk oleh cara penilaian analitik $\left(B_{1}\right)$ lebih besar dari pada kelompok siswa yang dibentuk oleh cara penilaian holistik $\left(B_{2}\right)$ setelah mengontrol pengetahuan awal matematika siswa; dan (14) menunjukkan bahwa nilai statistik Uji-t diperoleh nilai $t_{\text {hit }}=7,272>\mathrm{t}_{\text {tab }}=1,697$ artinya bahwa hasil belajar IPA kelompok siswa yang diberi model penilaian diri $\left(A_{3}\right)$ yang dibentuk oleh cara penilaian analitik $\left(B_{1}\right)$ lebih besar dari 
pada kelompok siswa yang dibentuk oleh cara penilaian holistik $\left(B_{2}\right)$ setelah mengontrol pengetahuan awal matematika siswa.

\section{Pembahasan}

Penelitian ini secara umum dilakukan dengan tujuan untuk memperoleh gambaran lebih lengkap tentang pengaruh perlakuan model dan cara penilaian terhadap hasil belajar IPA dengan mengontrol pengetahuan awal matematika siswa. Perlakuan ini diterapkan pada tiga sekolah yang ada di kecamatan Bula kabupaten Seram Bagian Timur Provinsi Maluku, yakni: SMP Negeri I, SMP Negeri 2, dan SMP Negeri 3 Bula sebagai kelompok yang diberi model penilaian tes tertulis $\left(A_{1}\right)$, penilaian antar teman $\left(A_{2}\right)$, dan penilaian diri $\left(A_{3}\right)$. Selanjutnya masing-masing kelas dibagi dalam dua kelompok siswa yang masing-masing diberi cara penilaian analitik $\left(B_{1}\right)$ dan cara penilaian holisitik $\left(B_{2}\right)$. Proses pembahasan dilakukan secara rinci dari setiap variabel berdasarkan hasil temuan penelitian dan berdasarkan pengujian hipotesis sebagai berikut.

\section{Hipotesis Khusus Model Penilaian}

Hasil pengujian hipotesis penelitian menyatakan secara umum terdapat perbedaan hasil belajar IPA siswa antar kelompok yang dibentuk oleh cara penilaian (B) dengan diberikan model penilaian (A) yang berbeda. Perbedaan ini terlihat dari hasil Uji-F dan hasil dekriptif. Dalam hasil belajar IPA kelompok siswa yang diberikan model penilaian antar teman memiliki nilai rataratanya lebih tinggi dari kelompok siswa yang diberi model penilaian tes tertulis dan model penilaian diri pada setiap cara penilaian setelah mengontrol pengetahuan awal matematika siswa. Secara rinci perbedaan rerata hasil belajar siswa antar kelompok yang diberikan model penilaian berbeda sebagai berikut:

I.a. Terdapat perbedaan rerata simpangan hasil belajar IPA siswa kelompok yang diberikan model penilaian tes tertulis dengan kelompok siswa yang diberi model penilaian antar teman setelah mengontrol pengetahuan awal matematika siswa
Kesimpulan yang tergambarkan di atas diperkuat dengan hasil analisis deskriptif yang terlihat bahwa nilai rerata hasil belajar IPA pada kelompok siswa yang diberi model penilaian tes tertulis adalah sebesar $\left(\mu \mathrm{A}_{1}=84,27\right)$ dengan kelompok siswa yang diberi model penilaian antar teman adalah $\left(\mu \mathrm{A}_{2}=8 \mathrm{I}, 68\right)$ dengan demikian dapat diartikan bahwa dalam pelaksanaan proses pembelajaran IPA di sekolah, terutama pada jenjang sekolah menengah pertama (SMP) dalam membangkitkan motivasi belajar siswa maka guru perlu melakukan variasi di dalam melakukan penilaian hasil belajar. Hal ini disebabkan dari hasil penelitian menggambarkan bahwa kelompok siswa yang diberi model penilaian tes tertulis pada setiap cara penilaian lebih tinggi jika dibandingkan dengan kelompok siswa yang diberi model penilaian antar teman pada setiap cara penilaian setelah mengontrol pengetahuan awal matematika siswa.

Berdasarkan pembahasan di atas, maka pemberian penilaian tes tertulis pada proses pembelajaran lebih tinggi hasilnya jika dibandingkan dengan pemberian penilaian antar teman. Hal ini disebabkan dengan pemberian penilaian tes tertulis yang disusun secara sistematis sesuai dengan ciri materi IPA maka dapat membangkitkan gairah siswa dalam belajar hal ini disebabkan siswa sadar akan kelebihan dan kelemahan dirinya, dengan seseorang yang sadar akan kelebihan dan kekurangan dirinya membuat siswa tersebut lebih giat lagi dalam belajar sehingga dapat meningkatkan kemampuan yang ada pada dirinya.

I.b.Terdapat perbedaan rerata simpangan hasil belajar IPA siswa kelompok yang diberikan model penilaian tes tertulis dengan kelompok siswa yang diberi model penilaian diri setelah mengontrol pengetahuan awal matematika siswa

Pada hasil analisis deskriptif terlihat bahwa nilai rerata hasil belajar IPA pada kelompok siswa yang diberikan model penilaian tes tertulis adalah sebesar $\left(\mu \mathrm{A}_{1}=84,27\right)$ dengan kelompok siswa yang diberi model penilaian diri adalah $\left(\mu \mathrm{A}_{3}=\right.$ 8I,65). Sehingga dapat disimpulkan bahwa hasil belajar IPA siswa yang diberi model penilaian diri 
pada setiap cara penilaian lebih tinggi dibandingkan dengan kelompok siswa yang diberi model penilaian tes tertulis pada setiap cara penilaian setelah mengontrol pengetahuan awal matematika siswa. Pada kajian teori terlihat bahwa pemberian tes tertulis dimaksudkan untuk mengembangkan secara penuh respon siswa. Karena tes tertulis merupakan himpunan pertanyaan yang harus dijawab oleh seorang yang dites dengan tujuan untuk mengukur suatu aspek (perilaku) tertentu dari orang yang dites. Penilaian tes tertulis merupakan suatu metoda yang efektif untuk menilai pengetahuan, fakta, dan keterampilan yang disusun melalui prosedur yang sistematis sehingga dapat digunakan untuk menilai proses perubahan kognitif maupun tingkah laku yang terjadi pada diri siswa. Penilaian tes tertulis mengharuskan siswa dapat membaca, mengarang, ataupun memahami konsep yang ditunjukkan secara simbolis. Oleh sebab itu, penilaian tes tertulis memungkinkan dilakukan secara bertahap sebagai bagian dari penilaian siswa secara keseluruhan di dalam proses pembelajaran di kelas.

Berdasarkan pembahasan di atas, maka pemberian penilaian tes tertulis pada proses pembelajaran lebih tinggi hasilnya jika dibandingkan dengan pemberian penilaian diri. Hal ini dikarenakan pemberian penilaian tes tertulis dapat membuat siswa harus menyiapkan diri dengan matang sebelum mengikuti tes. Karena dengan menyiapkan diri itu maka siswa diharapkan dapat menjawab semua himpunan pertanyaan yang akan diujikan.

I.c. Terdapat perbedaan rerata simpangan hasil belajar IPA siswa kelompok yang diberikan model penilaian antar teman dengan kelompok siswa yang diberi model penilaian diri setelah mengontrol pengetahuan awal matematika siswa

Hasil analisis deskriptif terlihat bahwa nilai rerata hasil belajar IPA pada kelompok siswa yang diberi model penilaian antar teman adalah sebesar $\left(\mu A_{2}=8 I, 68\right)$ dengan kelompok siswa yang di beri model penilaian diri adalah $\left(\mu \mathrm{A}_{3}=81,65\right)$. Sehingga dapat disimpulkan bahwa hasil belajar IPA siswa yang diberi model penilaian tes tertulis pada setiap cara penilaian lebih tinggi dibandingkan dengan kelompok siswa yang diberi model penilaian diri pada setiap cara penilaian setelah mengontrol pengetahuan awal matematika siswa. Hasil tersebut di atas dapat didukung dengan kajian teori tentang penilaian antar teman bahwa penilaian antar teman (peer assessment) merupakan suatu model penilaian yang dilakukan dengan cara meminta peran peserta didik untuk memberikan penilaian kepada sesama siswa dengan jalan mengemukakan kelebihan dan kekurangan dari temannya dalam berbagai hal yang berhubungan dengan proses pembelajaran. Karena dengan melibatkan siswa dalam proses penilaian maka dapat mengembangkan kemampuan siswa dalam bekerja sama, bersikap kritis terhadap hasil kerja siswa lain, dan menerima kritik dan umpan balik dari siswa lain atas hasil kerjanya sendiri. Penilaian antar teman juga dapat memberikan gambaran kepada siswa mengenai kriteria yang digunakan dalam menilai. Selain itu penilaian antar teman juga dapat digunakan untuk menentukan nilai hasil kerja siswa untuk keperluan formatif maupun sumatif.

Keunggulan dari model penilaian antar teman jika dibandingkan dengan model penilaian diri sebagaimana dikemukakan oleh Bostock, adalah membantu siswa untuk bertanggung jawab dengan dilibatkan dalam penilaian, mendorong siswa utuk kritis meneliti pekerjaan yang dilakukan rekannya, memberikan umpan balik bagi siswa, sebagai latihan bagi siswa untuk terjun didunia kerja, di mana penilaian dilakukan oleh kelompok, mengurangi beban guru dan meningkatkan motivasi siswa, meningkatkan motivasi siswa, karena siswa merasa memiliki proses penilaian, mendidik siswa menjadi pembelajar yang mandiri, karena peer assesment mendorong mereka untuk lebih peduli terhadap kehidupan belajarnya masing-masing.

2. Terdapat perbedaan hasil belajar IPA siswa kelompok yang diberikan cara penilaian analitik dengan kelompok siswa yang diberi cara penilaian holistik setelah mengontrol pengetahuan awal matematika siswa

Pada kajian teori terlihat bahwa cara penilaian analitik adalah cara penilaian yang mengharuskan para penilai dapat menentukan 
daftar unsur-unsur penting yang harus dinilai. Sedangkan menurut Metler (diakses tanggal 18 Oktober 2010: 2) cara penilaian analitik adalah setiap hasil kinerja (performance) individu dinilai, selanjutnya nilai individu dijumlahkan untuk memperoleh nilai total. Lebih lanjut dijelaskan bahwa cara penilaian analitik adalah biasanya lebih menginginkan nilai yang berfokus pada keadilan penilaian berdasarkan jenis jawaban yang diperlukan, karena itu tugas-tugas kinerja yang dapat diterima sebagai jawaban siswa boleh diberi nilai satu atau dua, kendatipun kreativitas bukan suatu ciri yang paling esensial dari jawaban siswa.

Sementara itu secara teori cara penilaian holistik didefinisikan sebagai suatu bentuk penilaian yang memberikan penilaian secara menyeluruh tanpa memperhatikan tahapantahapan dan urut-urutan dalam penilaian. Karena itu cara penilaian holistik lebih memandang pada hasil akhir dalam kaitannya dengan kontribusi tugas secara keseluruhan. Hubungan di antara poin ditentukan dengan uraian hasil kinerja atau kontribusi kinerja secara keseluruhan. Cara penilaian holistik terbukti lebih cepat dan efisien, sebab satu cara menyediakan untuk keseluruhan kemampuan dari beberapa hasil kinerja.

Penjelasan teori di atas sejalan dengan temuan penelitian dengan hasil analisis deskriptif terlihat bahwa nilai rerata hasil belajar IPA pada kelompok siswa yang dibentuk oleh cara penilaian holistik adalah sebesar $\left(\mu B_{1}=81,04\right)$ sedangkan kelompok siswa yang dibentuk oleh penilaian analitik adalah sebesar $\left(\mu B_{2}=84,02\right)$ ini berarti terdapat perbedaan hasil belajar IPA siswa antar cara penilaian holistik dan cara penilaian analitik. $\mathrm{Hal}$ ini diperjelas dengan hasil Uji-t pada bagian yang terlihat bahwa nilai $t_{\text {hit }}=2,|3|>t_{\text {tabel }}=$ I,697 sehingga dapa disimpulkan bahwa tolak $\mathrm{H}_{0}$ artinya bahwa nilai rerata kelompok siswa yang dibentuk oleh cara penilaian analitik $\left(B_{1}\right)$ lebih besar dari nilai rerata kelompok siswa yang dibentuk oleh cara penilaian holistik $\left(B_{2}\right)$ setelah mengontrol pengetahuan awal matematika siswa.

3. Terdapat interaksi antar faktor model penilaian dengan faktor cara penilaian setelah mengontrol pengetahuan awal matematika siswa
Berdasarkan hasil pengujian hipotesis dari penelitian ini menunjukkan adanya interaksi antar model dan cara penilaian terhadap hasil belajar IPA, dengan mengontrol pengetahuan awal matematika siswa. Hasil penelitian menunjukkan bahwa adanya pengaruh dari hubungan saling ketergantungan antar model penilaian dengan cara penilaian terhadap hasil belajar IPA siswa. Hasil penelitian ini ditunjukkan oleh hasil analisis di mana $F_{\text {hit }}=12,945>F_{\text {tab }}=2,70$. Hasil ini menunjukkan bahwa data penelitian ini mendukung kebenaran hipotesis yang diajukan. Kesimpulan ini diperkuat dengan nilai statistik deskriptif, yang menunjukkan adanya pengaruh hubungan timbal balik (saling ketergantungan) seperti yang ditunjukkan secara visual dalam Tabel 2 berikut ini:

Tabel 2. Komposisi Hasil Belajar IPA Setiap Kelompok Penelitian

\begin{tabular}{|c|c|c|c|c|}
\hline $\begin{array}{c}\text { Cara } \\
\text { Penilaian } \\
(B)\end{array}$ & $\begin{array}{c}\text { Tes } \\
\text { Tertulis } \\
\left(A_{1}\right)\end{array}$ & $\begin{array}{c}\text { Antar } \\
\text { Teman } \\
\left(A_{2}\right)\end{array}$ & $\begin{array}{c}\text { Diri } \\
\left(A_{3}\right)\end{array}$ & Jumlah \\
\hline $\begin{array}{c}\text { Analitik } \\
\left(B_{1}\right)\end{array}$ & 86,41 & 82,24 & $8 I, 4 I$ & 84,02 \\
\hline $\begin{array}{c}\text { Holistik } \\
\left(B_{2}\right)\end{array}$ & 82,12 & $8 I, 12$ & 79,88 & $8 I, 04$ \\
\hline Jumlah & 84,27 & $8 I, 68$ & $8 I, 65$ & 82,53 \\
\hline
\end{tabular}

Dari gambaran tersebut terlihat bahwa perbedaan hasil belajar IPA siswa antar sel setelah mengontrol pengetahuan awal matematika siswa sangat ditentukan oleh model penilaian dan cara penilaian yang memberikan informasi bahwa: (I) khusus kelompok siswa yang diberi model penilaian tes tertulis, hasil belajar IPA siswa yang dibentuk oleh cara penilaian analitik $\left(\mu_{12}=86,4 \mathrm{I}\right)$, lebih tinggi dari hasil belajar kelompok siswa yang dibentuk oleh cara penilaian holistik $\left(\mu_{11}=82,12\right)$, (2) khusus kelompok siswa yang diberi model penilaian antar teman, hasil belajar IPA siswa yang dibentuk oleh cara penilaian analitik $\left(\mu_{22}=82,24\right)$, lebih tinggi dari hasil belajar kelompok siswa yang dibentuk oleh cara penilaian holistik $\left(\mu_{21}=81,12\right)$, (3) khusus kelompok siswa yang diberi model penilaian diri, hasil belajar IPA siswa yang dibentuk oleh cara penilaian analitik $\left(\mu_{32}=83,4 \mathrm{I}\right)$, lebih tinggi dari hasil belajar kelompok siswa yang 
dibentuk oleh cara penilaian holistik $\left(\mu_{31}=79,88\right)$, (4) khusus kelompok siswa yang dibentuk oleh cara penilaian holistik, hasil belajar IPA siswa yang diberi model penilaian tes tertulis $\left(\mu_{11}=82,12\right)$, lebih tinggi dari hasil belajar kelompok siswa yang diberi model penilaian antar teman $\left(\mu_{21}=8 I, I 2\right)$ dan kelompok siswa yang diberi model penilaian diri $\left(\mu_{31}=79,88\right)$, (5) khusus kelompok siswa yang dibentuk oleh cara penilaian analitik, hasil belajar IPA siswa yang diberi model penilaian tes tertulis $\left(\mu_{12}=86,4 \mathrm{I}\right)$, lebih tinggi dari hasil belajar kelompok siswa yang diberi model penilaian antar teman $\left(\mu_{22}=82,24\right)$ dan kelompok siswa yang diberi model penilaian diri $\left(\mu_{32}=83,4 I\right)$, khusus kelompok siswa yang dibentuk oleh cara penilaian holistik, hasil belajar IPA siswa yang diberi model penilaian antar teman $\left(\mu_{21}=8 I, 12\right)$, lebih tinggi dari hasil belajar kelompok siswa yang diberi model penilaian diri $\left(\mu_{31}=79,88\right)$, (7) khusus kelompok siswa yang dibentuk oleh cara penilaian analitik, hasil belajar IPA siswa yang diberi model penilaian diri $\left(\mu_{32}=83,4 \mathrm{I}\right)$, lebih tinggi dari hasil belajar kelompok siswa yang diberi model penilaian antar teman $\left(\mu_{22}=82,24\right)$, (8) khusus untuk semua model penilaian, hasil belajar IPA kelompok siswa dibentuk oleh cara penilaian analitik $\left(\mu_{24}=84,02\right)$, lebih tinggi dari hasil belajar IPA kelompok siswa yang dibentuk oleh cara penilaian holistik $\left(\mu_{14}=81,04\right)$.

Berdasarkan hasil pengujian hipotesis yang ditunjukkan pada Tabel 2 dan pembahasan di atas, maka dapat diberikan kesimpulan bahwa hasil belajar IPA siswa pada kelompok yang dibentuk oleh cara penilaian analitik untuk semua model penilaian lebih tinggi dari hasil belajar IPA siswa pada kelompok yang dibentuk oleh cara penilaian holistik setelah mengontrol pengetahuan awal matematika siswa. Hal ini dikarenakan bahwa cara penilaian analitik mengharuskan penilai melakukan suatu proses penilaian terhadap setiap kinerja siswa (hasil belajar) melalui daftar unsur-unsur penting yang harus dinilai berdasarkan kriteria setiap komponen tugas yang telah ditetapkan.

\section{Hipotesis khusus masing-masing cara penilaian}

4.a). Khusus untuk masing-masing cara penilaian analitik dan cara penilaian holistik, rerata simpangan hasil belajar siswa dalam kelompok yang menggunakan model penilaian tes tertulis lebih tinggi dari pada kelompok yang menggunakan model penilaian antar teman setelah mengontrol pengetahuan awal matematika siswa.

Hasil analisis pengujian hipotesis menunjukkan bahwa perolehan nilai statistiknya adalah $\mathrm{t}_{\text {hit }}=2,466$ lebih besar dari $\mathrm{t}_{\text {tab }}=1,697$ sehingga dapat disimpulkan bahwa khusus kelompok siswa yang dibentuk oleh cara penilaian analitik dan cara penilaian holistik yang diberi model penilaian tes tertulis dan model penilaian antar teman terdapat perbedaan hasil belajar IPA kelompok siswa antara kedua kelompok setelah mengontrol pengetahuan awal matematika siswa.

$\mathrm{Hal}$ ini diperkuat dengan hasil analisis statistik deskriptif terlihat bahwa nilai rerata hasil belajar IPA khusus pada kelompok siswa yang dibentuk oleh cara penilaian analitik dengan diberi model penilaian tes tertulis adalah $\left(\mu \mathrm{A}_{1}=\right.$ 82,12 ) sedangkan yang diberi model penilaian antar teman adalah $\left(\mu A_{2}=8 I, I 2\right)$. Sedangkan khusus untuk kelompok siswa yang dibentuk oleh cara penilaian holistik dengan diberi model penilaian tes tertulis adalah $\left(\mu \mathrm{A}_{1}=86,4 \mathrm{I}\right)$ dan kelompok siswa yang diberi model penilaian antar teman adalah $\left(\mu \mathrm{A}_{3}=82,24\right)$, dengan demikian di sini terlihat hasil perhitungan menunjukkan bahwa khusus kelompok siswa yang diberi penilaian tes tertulis hasil belajar IPA lebih tinggi dari pada kelompok siswa yang diberi model penilaian antar teman pada semua cara penilaian setelah mengontrol pengetahuan matematika siswa. Hasil tersebut di atas didukung oleh kajian teori bahwa penilaian tes tertulis yang dilakukan secara terstruktur dan sistematis dengan menggunakan cara penilaian analitik maka akan mendorong kebiasaan siswa untuk belajar dan mendorong kebiasaan siswa untuk belajar secara teratur sehingga dapat meningkatkan hasil belajar IPA siswa.

4.b). Khusus untuk masing-masing cara penilaian analitik dan cara penilaian holistik, rerata simpangan hasil belajar siswa dalam kelompok yang menggunakan model penilaian tes tertulis lebih tinggi dari pada kelompok yang menggunakan model 
penilaian diri setelah mengontrol pengetahuan awal matematika siswa

Berdasarkan hasil analisis pengujian hipotesis diperoleh nilai $t_{\text {hit }}=2,622$ lebih besar dari $t_{\text {tab }}=1,697$ sehingga dapat disimpulkan bahwa khusus kelompok siswa yang dibentuk oleh cara penilaian analitik dan cara penilaian holistik yang diberi model penilaian tes tertulis dan model penilaian diri terdapat perbedaan hasil belajar IPA kelompok siswa antara kedua kelompok setelah mengontrol pengetahuan awal matematika siswa. Hal ini diperkuat dengan hasil analisis deskriptif yang terlihat bahwa nilai rerata hasil belajar IPA khusus pada kelompok siswa yang dibentuk oleh cara penilaian analitik dengan diberi model penilaian tes tertulis adalah $\left(\mu \mathrm{A}_{1}=\right.$ 82,12 ) sedangkan yang diberi model penilaian antar teman adalah $\left(\mu A_{2}=8 I, 12\right)$. Sementara khusus untuk kelompok siswa yang dibentuk oleh cara penilaian holistik dengan diberi model penilaian tes tertulis adalah $\left(\mu \mathrm{A}_{\mathrm{I}}=86,4 \mathrm{I}\right)$ dan kelompok siswa yang diberi model penilaian antar teman adalah $\left(\mu \mathrm{A}_{2}=82,24\right)$, dengan demikian di sini terlihat hasil perhitungan menunjukkan bahwa khusus kelompok siswa yang diberi penilaian tes tertulis hasil belajar IPA lebih tinggi dari pada kelompok siswa yang diberi model penilaian antar teman untuk semua cara penilaian setelah mengontrol pengetahuan awal matematika siswa. Dari hasil ini diperkuat dengan kajian teori yang mengasumsikan bahwa model penilaian tes tertulis yang dilakukan secara terstruktur dan sistematis dengan menggunakan cara penilaian analitik maka akan memotivasi siswa untuk belajar sehingga dapat meningkatkan hasil belajar IPA siswa.

4.c). Khusus untuk masing-masing cara penilaian analitik dan cara penilaian holistik, rerata hasil belajar siswa dalam kelompok yang menggunakan model penilaian antar teman lebih tinggi dari pada kelompok yang menggunakan model penilaian diri setelah mengontrol pengetahuan awal matematika siswa

Hasil pengujian hipotesis menunjukkan bahwa khusus kelompok siswa yang dibentuk oleh cara penilaian analitik dan cara penilaian holistik yang diberi model penilaian antar teman dan model penilaian diri terdapat perbedaan hasil belajar IPA kelompok siswa antar kedua kelompok setelah mengontrol pengetahuan awal matematika siswa, hal ini terlihat dari perolehan nilai $t_{\text {hit }}=2,476$ lebih besar dari $t_{\text {tab }}=1,697$. Ini diperkuat dengan hasil analisis deskriptif di mana terlihat bahwa nilai rerata hasil belajar IPA khusus pada kelompok siswa yang dibentuk oleh cara penilaian analitik dengan diberi model penilaian antar teman adalah $\left(\mu \mathrm{A}_{2}=8 \mathrm{I}, \mathrm{I} 2\right)$ sedangkan yang diberi model penilaian diri adalah $\left(\mu \mathrm{A}_{3}=79,88\right)$. Sementara khusus untuk kelompok siswa yang dibentuk oleh cara penilaian holistik dengan diberi model penilaian antar teman adalah $\left(\mu \mathrm{A}_{2}=82,24\right)$ dan kelompok siswa yang diberi model penilaian diri adalah $\left(\mu \mathrm{A}_{3}\right.$ $=83,4 \mathrm{I})$, dengan demikian bahwa khusus kelompok siswa yang diberi penilaian antar teman hasil belajar IPA lebih tinggi dari pada kelompok siswa yang diberi model penilaian diri untuk cara penilaian analitik setelah mengontrol pengetahuan awal matematika siswa. Sedangkan pada kelompok yang dibentuk oleh cara penilaian holistik model penilaian diri lebih tinggi dari model penilaian antar teman.

\section{Hipotesis khusus untuk model penilaian}

5.a). Khusus untuk model penilaian tes tertulis, rerata simpangan hasil belajar siswa dalam kelompok yang menggunakan cara penilaian analitik lebih tinggi dari kelompok yang menggunakan cara penilaian holistik

Hasil analisis pengujian hipotesis perbedaan rerata simpangan hasil belajar menunjukkan bahwa nilai $t_{\text {hit }}=2,897$ dan nilai $t_{\text {tab }}=1,697$ dengan demikian berarti $\quad t_{\text {hit }}=2,897>t_{t a b}=1,697$ sehingga khusus kelompok siswa yang dibentuk oleh cara penilaian analitik dan cara penilaian holistik yang diberi model penilaian tes tertulis terdapat perbedaan hasil belajar IPA antara kedua kelompok setelah mengontrol pengetahuan awal matematika siswa. Hal ini diperkuat dengan hasil analisis statistik deskriptif terlihat bahwa nilai rerata hasil belajar IPA siswa yang diberi model penilaian tes tertulis khusus pada kelompok siswa yang dibentuk oleh cara penilaian analitik adalah $(\mu=86,4 I)$ sedangkan pada kelompok siswa yang dibentuk oleh cara 
penilaian holistik adalah $(\mu=82,12)$ dengan demikian dapat dikatakan bahwa khusus pada model penilaian tes tertulis, hasil belajar IPA kelompok siswa yang dibentuk oleh cara penilaian analitik $\left(B_{1}\right)$ lebih tinggi dari pada hasil belajar IPA kelompok yang dibentuk oleh cara penilaian holistik $\left(B_{2}\right)$ setelah mengontrol pengetahuan awal matematika siswa.

Pada kajian teori telah dijelaskan tentang cara penilaian analitik, di mana cara penilaian analitik merupakan suatu cara penilaian yang dilakukan secara terstruktur dan sistematis berdasarkan kaidah-kaidah yang ditetapkan. Jadi cara penilaian analitik selalu memperhatikan prosesnya, hal ini yang kemudian membuat siswa sadar akan kelemahan dan kekurangan dirinya sehingga membuat siswa termotivasi untuk lebih giat lagi di dalam belajar guna peningkatan prestasi belajar siswa.

5.b). Khusus untuk model penilaian antar teman, rerata simpangan hasil belajar siswa dalam kelompok yang menggunakan cara penilaian analitik lebih tinggi dari kelompok yang menggunakan cara penilaian holistik.

Berdasarkan Hasil analisis pengujian hipotesis khusus model penilaian antar teman pada kelompok yang dibentuk oleh cara penilaian analitik $\left(B_{1}\right)$ dan cara penilaian holistik $\left(B_{2}\right)$ diperoleh nilai $t_{\text {hit }}=3,747$ dan $t_{\text {tab }}=1,697$ dengan demikian nilai $t_{\text {hit }}=3,747>t_{\text {tab }}=1,697$ sehingga dapat dikatakan bahwa khusus kelompok siswa yang dibentuk oleh cara penilaian analitik dan cara penilaian holistik yang diberi model penilaian tes tertulis terdapat perbedaan hasil belajar IPA antara kedua kelompok setelah mengontrol pengetahuan awal matematika siswa. Hal ini diperkuat dengan hasil analisis deskriptif terlihat bahwa nilai rerata hasil belajar IPA siswa yang diberi model penilaian antar teman khusus pada kelompok siswa yang dibentuk oleh cara penilaian analitik adalah $(\mu=82,24)$ sedangkan pada kelompok siswa yang dibentuk oleh cara penilaian holistik adalah $(\mu=8 I, I 2)$ dengan demikian dapat dikatakan bahwa khusus pada model penilaian antar teman, rerata hasil belajar IPA kelompok siswa yang dibentuk oleh cara penilaian analitik lebih tinggi dari pada rerata hasil belajar kelompok siswa yang dibentuk oleh cara penilaian holistik setelah mengontrol pengetahuan awal matematika siswa.

Pada kajian teori telah dijelaskan tentang cara penilaian analitik, Shirran (2008: 5-7) di mana cara penilaian analitik merupakan suatu cara penilaian yang mempunyai banyak sekali manfaatnya bagi guru dan siswa, diantaranya: (I) memungkinkan guru memberikan alasan dan mendukung nilai yang diberikan kepada seorang siswa, andaikan ada siswa atau orang tua siswa yang menyampaikan keluhan, (2) memungkinkan siswa menjadi lebih baik menaksir kualitas pekerjaan mereka, (3) mudah menjelaskan kepada orang tua siswa dan memungkinkan orang tua siswa melihat apa yang perlu dilakukan anak itu untuk menaikkan angkanya, dan (4) memungkinkan guru mengurangi efek halo pada waktu memberi angka.

5.c). Khusus untuk model penilaian diri, rerata simpangan hasil belajar siswa dalam kelompok yang menggunakan cara penilaian analitik lebih tinggi dari kelompok yang menggunakan cara penilaian holistik

Berdasarkan Hasil analisis pengujian hipotesis tentang perbedaan rerata simpangan hasil belajar antara kelompok yang dibentuk oleh cara penilaian analitik dan cara penilaian holistik dengan menggunakan statistik Uji-t diperoleh nilai $\mathrm{t}_{\text {hit }}=7,272$ lebih kecil dari $\mathrm{t}_{\text {tab }}=1,697$ sehingga dapat dikatakan bahwa khusus kelompok siswa yang dibentuk oleh cara penilaian holistik dan cara penilaian analitik yang diberi model penilaian diri terdapat perbedaan hasil belajar IPA antara kedua kelompok setelah mengontrol pengetahuan awal matematika siswa. $\mathrm{Hal}$ ini diperkuat lagi dengan hasil analisis statistik deskriptif terlihat bahwa nilai rerata hasil belajar IPA siswa yang diberi model penilaian diri khusus pada kelompok siswa yang dibentuk oleh cara penilaian analitik adalah $(\mu=83,4 \mathrm{I})$ sedangkan pada kelompok siswa yang dibentuk oleh cara penilaian holistik adalah $(\mu=79,88)$ dengan demikian dapat dikatakan bahwa khusus model penilaian diri, hasil belajar IPA kelompok siswa yang dibentuk oleh cara penilaian analitik lebih tinggi dari pada hasil belajar IPA kelompok siswa yang dibentuk oleh cara penilaian holistik setelah mengontrol pengetahuan awal matematika siswa. 
Pada kajian teori telah dijelaskan bahwa cara penilaian analitik merupakan cara penilaian yang sistematis dan tersruktur dengan memperhatikan aspek-aspek yang dinilai, sehingga cara penilaian analitik banyak sekali manfaatnya bagi guru dan siswa diantaranya: (I) memugkinkan guru memberikan alasan dan mendukung nilai yang diberikan kepada seorang siswa, andaikan ada siswa atau orang tua siswa yang menyampaikan keluhan, (2) memungkinkan siswa menjadi lebih baik menaksir kualitas pekerjaan mereka, (3) mudah menjelaskan kepada orang tua siswa dan memungkinkan orang tua siswa melihat apa yang perlu dilakukan anak itu untuk menaikkan angkanya, dan (4) memungkinkan guru mengurangi efek halo pada waktu memberi angka. Sehingga dapat membangkitkan motivasi belajar siswa.

\section{Simpulan}

Kesimpulan yang diperoleh dari penelitian ini adalah: (I) hasil belajar IPA kelompok siswa yang diberi model penilaian tes tertulis (paper and pencils assessment) berbeda dengan kelompok siswa yang diberi model penilaian antar teman (peer assessment), dengan mengontrol pengetahuan awal matematika siswa, (2) hasil belajar IPA kelompok siswa yang diberi model penilaian tes tertulis (paper and pencils assessment) berbeda dengan kelompok siswa yang diberi model penilaian diri (self assessment), setelah mengontrol pengetahuan awal matematika siswa, (3) hasil belajar IPA kelompok siswa yang diberi model penilaian diri (self assessment) berbeda dengan kelompok siswa yang diberi model penilaian antar teman (peer assessment), dengan mengontrol pengetahuan awal matematika siswa, (4) hasil belajar IPA kelompok siswa yang diberi cara penilaian analitik berbeda dengan kelompok siswa yang diberi cara penilaian holistik, dengan mengontrol pengetahuan awal matematika siswa, (5) terdapat interaksi antara model penilaian dan cara penilaian terhadap hasil belajar IPA dengan mengontrol pengetahuan awal matematika siswa, (6) khusus kelompok siswa yang diberi cara penilaian analitik, terdapat perbedaan hasil belajar IPA antara model penilaian tes tertulis dan model penilaian diri, setelah mengontrol pengetahuan awal matematika siswa, (7) khusus kelompok siswa yang diberi cara penilaian analitik, terdapat perbedaan hasil belajar IPA antara model penilaian tes tertulis dan model penilaian antar teman dengan mengontrol pengetahuan awal matematika siswa, (8) khusus kelompok siswa yang diberi cara penilaian analitik terdapat perbedaan hasil belajar IPA antara model penilaian diri dan model penilaian antar teman dengan mengontrol pengetahuan awal matematika siswa, (9) khusus kelompok siswa yang diberi cara penilaian holistik terdapat perbedaan hasil belajar IPA antara model penilaian tes tertulis dan model penilaian diri, dengan mengontrol pengetahuan awal matematika siswa, (10) khusus kelompok siswa yang diberi cara penilaian holistik terdapat perbedaan hasil belajar IPA antara model penilaian tes tertulis dan model penilaian antar teman dengan mengontrol pengetahuan awal matematika siswa, (II) khusus kelompok siswa yang diberi cara penilaian holistik terdapat perbedaan hasil belajar IPA antara model penilaian diri dan model penilaian antar teman dengan mengontrol pengetahuan awal matematika siswa, (I2) khusus kelompok siswa yang menggunakan model penilaian tertulis terdapat perbedaan hasil belajar IPA antara cara penilaian analitik dan cara penilaian holistik dengan mengontrol pengetahuan awal matematika siswa, (I3) khusus kelompok siswa yang menggunakan model penilaian diri terdapat perbedaan hasil belajar IPA antara cara penilaian analitik dan cara penilaian holistik dengan mengontrol pengetahuan awal matematika siswa, dan (14) khusus kelompok siswa yang menggunakan model penilaian antar teman terdapat perbedaan hasil belajar IPA antara cara penilaian analitik dan cara penilaian holistik dengan mengontrol pengetahuan awal matematika siswa.

\section{Daftar Pustaka}

Bostock, Ronald, peer assessment, (http://www. ukcle.ac.uk/resources/assessment/group.ht $\mathrm{ml}$ ), (diakses tanggal 5 Oktober 20l0).

Djaali dan Puji Muljono. Pengukuran Dalam Bidang Pendidikan. Jakarta: Intermedia, 2000.

Ibrahim, Muslimin dan Muhammad, Nur. Pengajaran Berdasarkan Masalah. Surabaya: University Press, 2000. 
Kadir, Statistik untuk Penelitian Ilmu-ilmu Sosial. Jakarta: Rosemata Sampurna, 2012.

Metler, Craig A. Designing Scoring Rubrics for Your Classroom. Practical Assessment Research \& Evaluation, (http://PAREonline .net/getvn. asp? $v=7 \& n=25$ ), (diakses 18 Oktober 20I0).

Nitko, Anthony J. Educational Assessment of Students. New Jersey: Prentice Hall, 1996.

Popham, W. James. Classroom Assessment What Teachers Need to Know. Massachusetts: Allyn and Bacon, 2000.

Shirran Alax, Mengevaluasi Siswa, terjemahan Nien Bakti Soemanto, Jakarta: Grasindo, 2008.

Silverius, Suke, Evalusi Hasil Belajar dan Umpan Balik, Jakarta: Grasindo, I99I.

Tola, Burhanuddin. Prinsip-Prinsip dan Strategi Penilaian di Kelas. Jakarta: Badan Penelitian Pengembangan Departemen Pendidikan Nasional, 2006. 